\title{
Üniversite Öğrencilerinin Kendini Gerçekleştirme Düzeyi ile Benlik Saygıları Arasındaki İlişkinin İncelenmesi
}

\author{
Dilek ERZENLİ ALTUNBAYRAK*, Ferda Şule KAYA**
}

Öz

Bu çalışma üniversite öğrencilerinin kendilerini gerçekleştirme düzeyi ve benlik saygıları arasındaki ilişkiyi incelemektedir. Bu grubun lisans eğitimine devam edip etmemesi ile kendini gerçekleștirme ve benlik saygısı ilișkisinin önemli olduğu düşünülmüş ve konu sosyo-demografik değişkenler açısından da sorgulanmıştır. Bu çerçevede çalışmanın amacı; üniversitede meslek yüksekokulunda öğrenim gören öğrencilerinin benlik saygısı ile kendini gerçekleștirme değişkenleri arasındaki ilişkiyi incelemektir. Bu araștırmanın örneklemi 2016-2017 öğretim döneminde İstanbul'da 2 yll eğitim veren bir vakıf meslek yüksekokulunda öğretimine devam eden, 18-26 yaş arasındaki, 76 kız ve 59 erkek öğrenciden oluşmaktadır. Öğrenciler gönüllülük esasına göre seçilmiş ve anket çalışması yürütülmüştür. Verilerin analizinde ANOVA testi, t testi, Pearson korelasyon analizi, çoklu regresyon analizi yöntemleri kullanılmıştır. Araştırmanın sonucunda genel anlamda kendini gerçekleştirme ve benlik saygısı arasında anlamlı bir ilişki bulanamamıştır. Fakat alt boyutlar açısından bakıldığında; kız öğrencilerin ve orta gelirli ailelere sahip öğrencilerin "kendini gerçekleştirme düzeyi" yüksek bulunmuştur. "Zamanı iyi kullanma", "desteği içten alma", "başkalarıyla yakınlık kurabilme", "duyguları açıklama düzeyi", "içten geldiği gibi davranabilme”, "kendini gerçekleștiren değerleri benimseme", "saldırganlığın kabulü" alt boyut puanları açısından kız öğrenciler erkek öğrencilerden anlamlı derecede farklı bulunmuştur.

Anahtar Kelimeler: Kendini Gerçekleştirme, Benlik Saygısı, Üniversite Öğrencileri, Cinsiyet

\section{The Examination of the Relationship Between University Students Self-Actualisation Level and Their Self-Esteem}

\section{Abstract}

Main theme of thisstudy, which is envisioned as a field study, composes selfactualisation and self-esteem. Within this scope, analysing the relation between self-

\footnotetext{
Özgün Araștırma Makalesi (Original Research Article)

Geliş/Received: 15.10 .2018

Kabul/Accepted: 25.01 .2019

DOI: http://dx.doi.org/10.17336/igusbd.465990

*Uzm. Psk., İstanbul, Türkiye, E-posta: derzenli@gmail.com ORCID ID https://orcid.org/0000$\underline{0002-3747-7836}$

${ }_{* *}^{*}$ Dr., İstanbul Bilim Üniversitesi, Fen-Edebiyat Fakültesi, Psikoloji Bölümü, İstanbul, Türkiye, E-posta: kaya.s2565@gmail.com, sulekayabilim@gmail.com ORCID ID https://orcid.org/0000$\underline{0002-8415-8002}$
} 
Dilek Erzenli Altunbayrak, Ferda Şule Kaya, “Üniversite Öğrencilerinin Kendini Gerçekleștirme Düzeyi ile Benlik Saygları Arasındaki İlişkinin İncelenmesi”, İstanbul Gelişim Üniversitesi Sosyal Bilimler Dergisi, 6 (2), Ekim 2019, ss. 388-401.

actualisation and self-esteem, the relation between both behaviours and manners of these phenomenas as well as the sub-dimensions of these phenomenas are the objective of this study. The research sample consists of 135 students, 76 girls and 56 males between 1826 years old who continue their education in a foundation vocational school in Istanbul in 2016-2017 academic year. Students were selected on a voluntary basis and some surveys were conducted. For analysis of the data, ANOVA and T test, Pearson regression methods were used. As a result, no significant relation between self-actualisation and self-esteem was found in the research. A high significantly difference in the level of Self-Actualisation was found in students with middle-income families and girls. A high difference was found in the level of "Time Competence", "Inner Directed Support", "Capacity for Intimate Contact", "Feeling Reactivity", "Spontaneity"," Self Actualizing Value", " Acceptance of aggression" in girl students than male students. As a result, no significant relation between self-actualisation and self-esteem was found in the research. Significantly difference was found "self respect" level in first year students than second year students. A high levels was found "Inner Directed Support", "Spontaneity", "self respect", "Capacity for Intimate Contact", " Self Actualizing Value", "Existentiality" in the middle-income families than low-income and high- income families.

\section{Keywords: Self-Actualisation, Self-Esteem, University Students, Gender}

\section{Giriş}

İnsan doğumundan ölümüne kadar bir gelişim sürecinin içindedir. Bugüne kadar insanın gelişimini güdüleyenin ne olduğu konusunda çeşitli teoriler ortaya atılmıştır. Literatüre bakıldığında gelişimi güdüleyen çeşitli etkenler var olmakla birlikte benlik saygısı ihtiyacı da gelişimi güdüleyen etkenlerden biri olarak görülmektedir.

Alfred Adler, bebeğin eksiklik hissiyle doğduğunu, bu eksiklik hissinin benlik saygısını etkilediğini ve bu eksikliği tamamlamak için çaba gösterdiğini savunur. Ona göre insanın kişisel gelişimi bu eksiklik duygusundan kurtulma benlik saygısını kazanma çabasının bir sonucudur (Adler, 2014: s. 95).

Carl Rogers'a göre insan sadece fiziksel olarak gelişmek amacında değildir, kişisel gelişim için de çaba gösterir. Rogers bu güdünün "benlik doyumu (self-fulfilment)" ve "tam olarak fonksiyonda bulunma (fully functioning)" olarak iki kısımlı olduğundan bahseder. İdeal benlik ile gerçek benlik arasındaki farkın kişilik gelişimi için güdüleyici olduğunu savunur (Yanbastı, 1996: s. 252).

Maslow gelişimi İhtiyaçlar Hiyerarşisi Teorisi ile açıklamıştır. Maslow'un İhtiyaçlar Hiyerarşisi Teorisi, altta biyolojik ihtiyaçların olduğu, en üstte sosyal ve kişisel ihtiyaçların olduğu, aşağıdan yukarıya yükselen bir düzendir. Bu hiyerarşiye göre ancak alt basamaktaki ihtiyaçlar karşılandıktan sonra üst seviyedeki ihtiyaçlarımıza sıra gelir. Her basamaktaki ihtiyaç sırasıyla giderildiğinde bir üst basamaktaki ihtiyaç doğar (Plotnik, 2009: s. 443). Buna göre birey nihai basamak olan kendini gerçekleştirme basamağından önce kendine saygı ve başkalarından saygı görme ihtiyacını gidermiş olmalıdır. (Arık, 1992).

Maslow kendine saygı ihtiyacının iki şekilde olduğundan bahseder. Birisi kişinin kendi yeterliliğine, başarısına, uzmanlığına, ustalığına duyduğu saygıdır. Diğeri ise toplum tarafından kendine duyulan saygıdır; toplum içinde itibar görmek, şöhret sahibi olmak, hâkimiyet, saygınlık, takdir edilmedir. Bu durum dâhil olduğu kültürel özelliklerden de etkilenir (Maslow, 1970: s. 45).

Coopersmith ise benlik saygısını, kişinin kendini becerikli, başarılı ve değerli olarak algılama düzeyi şeklinde tanımlar. Coopersmith'e göre kişi kendi atıfları ve 
Dilek Erzenli Altunbayrak, Ferda Şule Kaya, “Üniversite Öğrencilerinin Kendini Gerçekleştirme Düzeyi ile Benlik Saygları Arasındaki İlişkinin İncelenmesi”, İstanbul Gelişim Üniversitesi Sosyal Bilimler Dergisi, 6 (2), Ekim 2019, ss. 388-401.

standartlarına göre kendi performansını, kapasitesini değerlendirir. Bu değerlendirme sonucuna göre kişi kendini değerli hisseder veya değerli hissetmez (Turan, 2010: s. 32,33). Coopersmith benlik saygısında toplumsal etkiden değil kişisel atıflardan bahsetmektedir.

Bu çalıșmanın konusu 18-26 yaş aralığındaki üniversite öğrencilerinin benlik saygısı ile kendini gerçekleştirme ve kendini gerçekleştirmenin alt boyutları arasındaki ilişkinin incelenmesidir. Ayrıca öğrencilerin benlik saygısı ve kendini gerçekleştirme düzeyi ile yaş, sınıf, çalışma durumu, gelecekleriyle ilgili beklentileri, anne ve babalarının eğitim durumu, anne ve babanın çalışıp çalıșmaması ve aile gelir düzeyinin ilișkisini incelemektir.

Konu ile ilgili literatür tarandığında kendini gerçekleștirme ve benlik saygısı ile ilgili ayrı ayrı birçok araștırmaya rastlanmış fakat kendini gerçekleștirme ve benlik saygısı arasındaki ilişkiye dair genellikle konuya paralel az sayıda çalıșmalara rastlanmıștır.

Üniversite öğrencilerinde benlik tasarımı ve kendini gerçekleştirme ilişkisi ile ilgili yapılan bir çalışmada benlik tasarımının olumlu veya olumsuz olması ile kendini gerçekleștirebilme arasında anlamlı bir farklılık bulunmamıștır (Sungur, 2008: s. 76).

Öğretmenlerle yapılan bir araștırmada toplumun kendilerine değer verildiğini hisseden öğretmenlerin kendini gerçekleștirme puanları, kendilerine değer verilmediğini hisseden öğretmenlerin kendini gerçekleștirme puanlarına göre anlamlı derecede yüksek bulunmuştur (Çelik, 1993) .

Literatürde kendini gerçekleștirme ve alt boyutlarının sosyo demografik özellikler ile ilişkisine bakıldığında bazı benzer ve paralel çalışmalara rastlanmıştır. Cinsiyetle kendini gerçekleștirme arasında ilişkiye dair yapılan bir çalışmaya göre bir grup kadın ve erkek mühendisin kendini gerçekleştirme düzeyi karşılaștırıldığında kadınların kendini gerçekleștirme düzeyi erkeklere göre daha yüksek bulunmuştur (Uzun, 2002: s. 131).

Kendini gerçekleştirmenin alt boyutlarından birisi olan desteği içten alma kendi kararlarını alırken otoriteye boyun eğmeme bağımsız olmayı ifade etmektedir. Buna paralel yapılan bir çalışmada erkeklerde boyun eğici davranışın kadınlara göre anlamlı derecede daha yüksek olduğu sonucuna varılmıştır (Kaya \& Uysal, 2015:654). Boyun eğici davranışlarla ilgili yapılan diğer çalışmada erkek öğrencilerin kızlara göre daha fazla uymacı (konformist) davranış geliștirme yönünde eğilimi olduğu, kız öğrencilerin otoriteye daha az uyum gösterdikleri görülmüștür (Kaya, Güneș, Kaya, \& Pehlivan, 2004: s. 7). Odacı (1994) ise yaptığı çalışmada başkalarıyla yakınlık kurabilme alt boyutunda üniversiteye devam eden kız öğrencilerin erkeklere göre yakın ilişkiler kurmada daha bașarılı oldukları sonucuna vardığı görülür (Odacı, 1994: s. 40).

Üniversite öğrencileriyle yapılan bir çalıșmada kız öğrenciler ve erkek öğrencilerin saldırganlık eğilimlerini kabul edebilme düzeyi karşılaștırıldığında kız öğrenciler lehine anlamlı farklılık bulunmuștur (Dünyalığulları, 2011: s. 60).

Literatüre bakıldığında öğrencinin kaçıncı sınıfta olduğu ile kendine saygı düzeyi ilişkisinin araştırıldığı çalışmalara rastlanmış, çalışmalardan farklı sonuçlar elde edilmiştir. Bu çalışmalardan birinde 1.sınıf öğrencilerinin benlik saygısı düzeyi 4.sınıf öğrencilerinin benlik saygısı düzeyine göre daha yüksek bulunmuştur (Torun \&Aslan,2012: s. 402).

Üniversite öğrencilerinin aile gelir düzeyi ile kendini gerçekleștirme alt boyutlarının ilişkisine bakılan bir çalışmada desteği içten alma, kendini gerçekleştirmeyi sağlayan değerleri benimseme, içinden istediği gibi davranabilme ve kendine saygı düzeyleri ile orta ve yüksek gelir grubuna dâhil olmaları arasında anlamlı ilișkiler bulunmuştur (Dünyalıoğulları, 2011: s. 65). Aile gelir düzeyi ile kendini gerçekleștirme arasındaki ilişkiye dair yapılan bir başka çalıșmada ailesinin gelir düzeyi orta ve yüksek 
Dilek Erzenli Altunbayrak, Ferda Şule Kaya, “Üniversite Öğrencilerinin Kendini Gerçekleștirme Düzeyi ile Benlik Saygları Arasındaki İlişkinin İncelenmesi”, İstanbul Gelişim Üniversitesi Sosyal Bilimler Dergisi, 6 (2), Ekim 2019, ss. 388-401.

olan gençlerin, kendini gerçekleștirme düzeylerinin yüksek olduğunu saptamıștır (Dağlı \&Beyazsaçli, 2010: s. 9).

Annenin çalışması ile çocuğun kendini gerçekleştirme alt boyutlarının ilişkisine dair literatüre bakıldığında paralel çalışmalara rastlanmıştır. Annenin çalışıyor olmasının çocuğun sosyal ilişkilerde başarılı, girişken ve kendine güvenli olmasını sağladığı görülmüştür (Gürsoy, Aral, Ayhan, \& Aydoğan, 2004: s. 67).

Literatürde babanın çalıșması ile kendini gerçekleştirme alt boyutlarının ilişkisine bakıldığında bu alt boyutlardan birisi olan "saldırganlığın kabulüne" paralel bir çalışmaya rastlanmıştır. Buna göre babası çalışmayan öğrencilerin şiddet eğilimlerinin çalışanlara göre daha yüksek olduğu belirtilmiștir (Özgür, Yörükoğlu, \& Arabacı, 2011: s. 57).

\section{Araștırmanın Amacı ve Önemi}

Bu çalıșma ile amaçlanan kendini gerçekleștirme düzeyi ve alt boyutları ile benlik saygısı arasında ilişki olup olmadığını belirlemektir. Ayrıca kendini gerçekleştirmenin alt boyutları ile demografik özellikler arasındaki ilișkileri incelemektir.

"Kendini gerçekleştirme düzeyi ile benlik saygısı düzeyi arasındaki ilişki var mıdır", "Kendini gerçekleştirmenin alt boyutları ile benlik saygısı arasında ilişki var mıdır", "Kendini gerçekleștirmenin alt boyutları ile demografik özellikler arasında ilișki var mıdır" sorularına bu çalışmayla cevap bulunmaya çalışılacaktır.

\section{Yöntem}

\subsection{Araştırma Modeli}

$\mathrm{Bu}$ araştırmanın modeli niceliksel genel tarama modelidir. Öğrencilerin kendini gerçekleştirme açısından bulunduğu düzey ile benlik saygısı arasındaki ilişkiyi incelemek amacıyla betimsel bir çalıșma olup ilișkisel tarama modeli kullanılmıștır. Araștırmada öğrencilerin kendini gerçekleştirme açısından bulunduğu düzey ile benlik saygısı düzeyi arasındaki ilişkiyi ve her iki envanterin alt ölçekleri arasındaki ilişkiyi belirleyebilmek için korelasyonel analiz yöntemi kullanılmıştır.

\subsection{Evren ve Örneklem}

$\mathrm{Bu}$ araștırmanın evreni İstanbul'daki üniversite öğrencileridir. Araştırmanın örneklemi ise 2016-2017 eğitim döneminde özel bir vakıf meslek yüksekokulunun çeşitli bölümlerinde 1. ve 2. sinıflara devam eden üniversite öğrencilerinden oluşmaktadır. Araștırmaya katılan öğrenciler gönüllülük esasına göre seçilmiștir.

\subsection{Veri Toplama Araçları}

Araştırmada araştırmacı tarafından öğrencilerin sosyo-demografik özelliklerini geliştirilen "Kişisel Bilgi Formu"; öğrencilerin benlik saygısı puanlarını belirlemek için Coopersmth (1967) tarafından geliștirilen "Coopersmith Benlik Saygısı Envanteri"; kendini gerçekleştirme puanlarını belirlemek için ise Everett Storm (1968) tarafından geliştirilen "Kişisel Yönelim Envanteri” kullanılmıştır.

Kişisel Bilgi Formu: Araştırmaya katılanların sosyo-demografik özelliklerini ölçmek için oluşturulan 13 sorudan oluşan bir bilgi formudur. Bu bilgi formun soruları öğrencilerin araştırmaya konu olan benlik saygısı ve kendi gerçekleştirme düzeylerini etkileyeceği düşünülen sorulardan oluşmaktadır. 
Dilek Erzenli Altunbayrak, Ferda Şule Kaya, “Üniversite Öğrencilerinin Kendini Gerçekleștirme Düzeyi ile Benlik Saygları Arasındaki İlişkinin İncelenmesi”, İstanbul Gelişim Üniversitesi Sosyal Bilimler Dergisi, 6 (2), Ekim 2019, ss. 388-401.

Bu sorular öğrencilerin cinsiyeti, kaçıncı sınıfta okudukları, 5 yıl sonra kendini nerede görmek istediği, ailelerinin gelir durumları, anne baba çalışıyor mu ve doğum sırası ile ilgili bilgileri edinmeye yönelik sorulardır.

Coopersmith Benlik Saygısı Envanteri (Coopersmith Self Esteem Inventory): $\mathrm{Bu}$ çalışmada benlik saygısı puanları Coopersmith benlik saygısı envanterinin yetișkin formu kullanılarak tespit edilmiştir. Bu envanterde geçerli olan benlik kavramı "Kişinin kendisi için onayladığı ya da onaylamadığı bazı özellikleriyle ilgili değerlendirmesi veya kendisi hakkındaki yargısıdır." (Turan \& Tufan, 1989: s. 30). Envanterin maddeleri bireyin hayata dair bakış açısını ve bireyin aile ilişkileri, sosyal ilişkilerini içeren cümlelerden oluşmaktadır. Envanter kişinin "bana uygun" veya "bana uygun değil" seçeneklerinden en az birini işaretleyerek cevap vereceği yetişkin formu 25 maddeden oluşur. Bireyin ölçekten aldığı 0-100 arasındaki puanlara göre düşük, orta veya yüksek benlik saygısı düzeyine sahip olduğu değerlendirilir. Ölçekten alınan yüksek puan yüksek benlik düşük puan düşük benlik saygısı olarak değerlendirilir (Turan \& Tufan, 1989).

Kişisel Yönelim Envanteri (Personal Orientation Inventory): Bu envanter Everett Storm (1968) tarafından, Rogers ve Maslow'un kuramlarına dayandırılarak geliştirdiği, kişinin kendini gerçekleştirme düzeyini belirlemek için kullanılan bir ölçektir. Türkçe uyarlaması 1973 yılında Yıldız Kuzgun tarafından yapılmıştır. Kişisel yönelim envanteri 150 maddeden oluşur. Her madde kendini gerçekleştiren ve kendini gerçekleştirmeyen cümleleri içeren iki şıktan oluşmaktadır. Bireyler verilen çift ifadelerden birini seçmek zorundadır. Kişisel yönelim envanteri "zamanı iyi kullanma" ve "desteğini içeriden alma" olmak üzere iki ana ölçek ve 10 tane alt testten oluşmaktadır (Kuzgun \&Bacanlı, 2005: s. 31). Bu çalışmada "kendini kabul edebilme" ve "insan doğası hakkında olumlu görüş sahibi olma" alt ölçekleri hariç diğer alt ölçekler kullanılmıştır.

Kişisel Yönelim Envanterinin bu çalışmada kullanılan alt testlerinin tanımı ve içeriği aşağıdaki gibidir (Kuzgun \&Bacanlı, 2005: s. 31).

Zamanı iyi kullanma: İçinde bulunduğu zamanda yaşama, geçmiş zamanı ve geleceği içinde bulunduğu zamana makul bir devamlılıkla bağlayabilme; geçmișe dair pişmanlık gibi negatif duygular yaşamadan geçmişe bakabilme; geleceğe yönelik planlarında gerçekçi olabilme.

Desteği içten alma: Dışarıdan bir otoriteye göre değil içsel (internal) otoriteye göre davranışlarını şekillendirmeme; başkalarına bağımlı olmayı azaltma, kendi kendine yetebilme.

Kendini gerçekleştirmeye götüren değerleri benimseme: Kendini gerçekleştiren bireylerin değerlerini ve davranış şekillerini benimseme; yaşamını çevre baskısından etkilenmeden sürdürme, gizil güçlere güvenme ve bunları gerçekleștirme.

Varoluşsal hayat sürme: Standartları ve prensipleri uygulamada esneklik gösterme, dış ölçütlere ve diğerlerinin isteklerine sert șekilde bağlı ve dogmatik olmama.

Duyguları açıklama: Duygularını fark etme; onları gizleme, susturmak, itiraz etme gereğini duymama.

İçten geldiği gibi davranabilme: Duygularını, istek ve taleplerini düzgün ifade etmeyi, istediği şekilde tepkide verebilmeyi ve bunların mesuliyetini alabilme,

Kendine saygı: Bireyin kendi kişiliğini güçlü bir kişilik olarak algılaması ve bu yüzden saygı gösterme; pozitif öz kavramına sahip olma,

Dünyaya uzlaştırıcı gözle bakabilme: Dünyadaki zıtlara daha geniş bir çerçeveden bakabilme ve bunların aslında anlamlı bir şekilde ilişki içinde olduklarını görebilme,

Saldırganlık eğilimlerini kabul edebilme: Hiddet ve şiddet eğilimlerinin bilincinde olma ve bu eğilimleri kişiliğinin parçası olarak kabul edebilme,

Başkaları ile yakınlık kurabilme: Diğer bireylere pozitif duygular içerisinde yaklaşabilme; samimi, makul birliktelikler kurup sürdürebilme, 


\subsection{Verilerin Toplanması ve İstatistiksel Analiz}

Araștırmanın örneklemi İstanbul'da bir vakıf meslek yüksekokulunda 2016-2017 öğretim yılında birinci ve ikinci sınıflara devam eden, kolayda örneklem yöntemi ile seçilen ve ulaşılabilen 135 öğrenciden oluşmaktadır. Örnekleme dâhil olan öğrencilere Kişisel Yönelim Envanteri Ve Coopersmith Benlik Saygısı Envanteri ve Kişisel Bilgi Formları verilerek süre kısıtlaması olmadan maddeleri kalemle işaretleyerek cevaplandırmaları istenmiștir. Verilerin analizine başlanmadan önce, veri toplama araçları tek tek kontrol edilerek sıralanmış, veri toplama araçları yoluyla elde edilen veriler tanımlanmış ve SPSS programına yüklenmiștir. IBM SPSS 24 paket programı kullanılarak bilgisayar ortamında gerçekleştirilmiştir. $\mathrm{Bu}$ veriler araştırmanın problemlerine göre analiz edilmiştir. Normallik varsayımı karşılandığı için parametrik testler uygulanmıștır. Sonuçların analiz edilmesinde anlamlılık düzeyi 0,05 üst değer olarak alınmıștır. Verilerin analizinde ANOVA ve t testi kullanılmıștır. Ailenin gelir durumu, anne ve babanın eğitim durumu ve doğum sırası ile ilgili verilerde ANOVA testi uygulanmış; cinsiyet, yaş, 5 yıl sonra ne yapmak istediği, okuduğu sınıf, çalışma durumu, anne ve babanın çalışma durumu ile ilgili ise t Testi uygulanmıștır.

Coopersmith benlik saygısı toplam puanları ile kişisel yönelim envanteri toplam puanları arasındaki ilişkiler Pearson korelasyon analiz yöntemiyle ile hesaplanmıştır. Öğrencilerin kişisel yönelimleri ve benlik saygısı düzeyleri üzerindeki yordayıcılık etkisi çoklu regresyon analiz yöntemleriyle incelenmiștir.

\section{Bulgular}

\subsection{Araştırmaya Katılan Öğrencilerin Sosyo-Demografik Özellikleri}

Araștırmanın evreni 2016-2017 eğitim öğretim yılında Bir Vakıf Meslek Yüksekokulunun birinci ve ikinci sınıflarında öğrenim görmekte olan, birinci ve ikinci öğretime devam eden öğrenciler olușturmaktadır. Araștırmanın örneklemi bir vakıf meslek yüksekokulunda 2016-2017 öğretim yllında birinci ve ikinci sinıflara devam eden, kolayda örneklem yöntemi ile seçilen ve ulaşılabilen 135 öğrenciden oluşmaktadır.

Araştırmaya katılan öğrencilerin; \%56.3'ü kadın, \%50.4'ü 18-20 ve \%49.6'sı 21yaş ve üzeridir. \%49.6'sı birinci sınıf, ailenin gelir durumu açısından \%34.8'i (0-2000 TL), \%48.1'i (2100-4000), \%17'si (4100 ve üzeri) olarak belirtilmiștir. Ayrıca; \%30.4'ünün annesi çalışırken, \%78.5'inin babası çalışmaktadır. Doğum sırası açısından kaçıncı sırada doğduğu sorusuna ise; \%39.3 birinci çocuk,\%32.6 ikinci çocuk,\%28.1 son çocuk olarak ifade edilmiștir.

\section{Bulgular \\ 4.2.Kendini Gerçekleştirme Düzeyi ve Benlik Saygısı Arasındaki İlişkiye Dair}

Araştırmada kendini gerçekleştirme düzeyi ve benlik saygısı arasında ilişki olup olmadığını anlamak amacıyla Pearson korelasyon analizi yapılmıștır. Analiz sonucunda, öğrencilerin kendini gerçekleștirme düzeyi envanteri puanları ile benlik saygısı envanteri puanları arasında istatistiksel açıdan anlamlı bir ilişki bulunmamıştır $(r=0,086 ; p>0,05)$.

\section{3.Öğrencilerin Kendini Gerçekleştirme Düzeyi ile Cinsiyet ve Ailenin Gelir Düzeyi Arasındaki İliş̧iye Dair Bulgular}

Tablo 1'de Öğrencilerin kendini gerçekleştirme düzeylerinin ailenin gelir düzeyi ve cinsiyet değişkeni açısından farklılașıp farklılașmadığı üzerine yapılan analizlerin sonucu görülmektedir. 


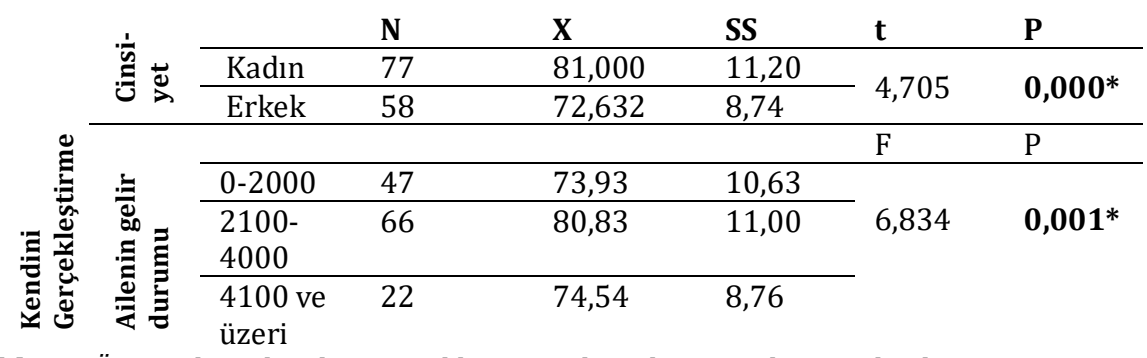

Tablo 1: Öğrencilerin kendini gerçekleștirme düzeylerinin ailenin gelir düzeyi ve cinsiyet değişkeni açısından farklılașıp farklılaşmadığı üzerine yapılan Bağımsız $t$ ve F Testinin Bulguları

Buna kız öğrencilerin ve orta gelirli aile üyesi gençlerin kendini gerçekleştirme düzeylerinin, diğerlerine göre anlamlı derecede farklı olduğu görülmüştür.

\subsection{Kişisel Yönelim Envanteri Alt Testleri ile Sosyo-Demografik Değişkenler Arasındaki İlişkiye Dair Bulgular Dair Bulgular \\ 4.4.1.Kendini Gerçekleştirme Alt Boyutları ve Cinsiyet Arasındaki İlişkiye}

Öğrencilerin kişisel yönelim envanteri alt boyutları toplam puanlarının "cinsiyet" değișkenine göre farklılaşıp farklılaşmadığını anlamak üzere yapılan t test bulguları tablo 2'de verilmiştir.

\begin{tabular}{|c|c|c|c|c|c|c|}
\hline & Cinsiyet & $\mathbf{N}$ & $\mathbf{X}$ & Ss & t & p \\
\hline \multirow{2}{*}{$\begin{array}{l}\text { Zamanı iyi } \\
\text { kullanma }\end{array}$} & Kadın & 77 & 13,50 & 2,44 & \multirow{2}{*}{6,022} & \multirow{2}{*}{$0,000^{* * *}$} \\
\hline & Erkek & 58 & 11,06 & 2,15 & & \\
\hline \multirow{2}{*}{$\begin{array}{l}\text { Desteği içten } \\
\text { alma }\end{array}$} & Kadın & 77 & 67,49 & 9,76 & \multirow{2}{*}{3,761} & \multirow{2}{*}{$0,000^{* * *}$} \\
\hline & Erkek & 58 & 61,56 & 7,96 & & \\
\hline \multirow[t]{2}{*}{ Duygusal açıklık } & Kadın & 77 & 14,37 & 2,93 & \multirow[b]{2}{*}{5,800} & \multirow{2}{*}{$0,000^{* * *}$} \\
\hline & Erkek & 58 & 11,60 & 2,48 & & \\
\hline \multirow[t]{2}{*}{ Kendine saygı } & Kadın & 77 & 11,49 & 2,35 & \multirow{2}{*}{3,444} & \multirow{2}{*}{ 0,001** } \\
\hline & Erkek & 58 & 10,06 & 2,40 & & \\
\hline \multirow{2}{*}{$\begin{array}{l}\text { Başkalarıyla } \\
\text { yakınlık } \\
\text { kurabilme }\end{array}$} & Kadın & 77 & 15,54 & 3,77 & \multirow[b]{2}{*}{5,361} & \multirow[b]{2}{*}{$0,000^{* * *}$} \\
\hline & Erkek & 58 & 11,87 & 4,12 & & \\
\hline \multirow{2}{*}{$\begin{array}{l}\text { İçten geldiği gibi } \\
\text { davranabilme }\end{array}$} & Kadın & 77 & 10,33 & 1,97 & \multirow{2}{*}{2,396} & \multirow{2}{*}{ 0,018* } \\
\hline & Erkek & 58 & 9,50 & 2,05 & & \\
\hline \multirow{2}{*}{$\begin{array}{l}\text { Kendini } \\
\text { gerçekleştiren } \\
\text { değerleri } \\
\text { benimseme }\end{array}$} & Kadın & 77 & 16,88 & 2,78 & \multirow[b]{2}{*}{2,691} & \multirow[b]{2}{*}{$\mathbf{0 , 0 0 8}{ }^{* *}$} \\
\hline & Erkek & 58 & 15,51 & 3,07 & & \\
\hline \multirow{2}{*}{$\begin{array}{l}\text { Saldırganlığın } \\
\text { kabulü }\end{array}$} & Kadın & 77 & 13,76 & 2,68 & \multirow{2}{*}{2,891} & \multirow{2}{*}{$0,004^{* *}$} \\
\hline & Erkek & 58 & 12,43 & 2,60 & & \\
\hline
\end{tabular}

Tablo 2: Öğrencilerin Kişisel Yönelim Envanteri Alt Boyutları ile Cinsiyet Arasındaki İlişki

Öğrencilerin zamanı iyi kullanma, desteği içten alma, duygusal açıklık, başkalarıyla yakınlık kurabilme, kendine saygı, kendini gerçekleștiren değerleri benimseme ve saldırganlığın kabulü alt testlerinden aldıkları puanlar cinsiyet değişkeni açısından karşılaştırıldığında yüksek düzeyde anlamlı farklılık gözlenmektedir. Söz konusu edilen boyutlar arasındaki farklılıkların hepsi kız öğrencilerin lehine gerçekleşmiştir. 
Öğrencilerin kişisel yönelim envanteri alt boyutları toplam puanlarının "5 yıl sonra kendini nerede görüyor?" değişkenine göre fark oluşup oluşmadığını anlamak üzere uygulanan bağımsız grup t testi sonucunda elde edilen bulgular tablo 3 'te verilmiștir.

\begin{tabular}{|c|c|c|c|c|c|c|}
\hline $\begin{array}{l}\text { Kişisel } \\
\text { yönelim } \\
\text { envanteri alt } \\
\text { boyutları }\end{array}$ & $\begin{array}{l}5 \text { yll } \\
\text { sonra } \\
\text { kendini } \\
\text { nerede } \\
\text { görüyor? }\end{array}$ & $\mathbf{N}$ & $\mathbf{x}$ & Ss & $\mathbf{t}$ & $\mathbf{p}$ \\
\hline \multirow{2}{*}{$\begin{array}{l}\text { Zamanı iyi } \\
\text { kullanma }\end{array}$} & Kariyer içi & 72 & 13,02 & 2,66 & \multirow{2}{*}{2,765} & \multirow{2}{*}{$0,007 *$} \\
\hline & $\begin{array}{l}\text { Kariyer } \\
\text { disl }\end{array}$ & 63 & 11,80 & 2,42 & & \\
\hline
\end{tabular}

Tablo 3: Zamanı Iyi Kullanma Alt Testi Toplam Puanlarının “5 Yıl Sonra Kendini Nerede Görüyor?” Değişkenine Göre Farklılaşıp Farklılaşmadığını Anlamak Üzere Yapılan Bağımsız Grup t Testi Bulguları

Tablo 3'de görüldüğü gibi öğrencinin “5 yıl sonra kendini nerede gördügü" değişkenine göre "zamanı iyi kullanma" alt boyutlarının aritmetik ortalamaları arasındaki fark istatistiksel olarak yüksek düzeyde anlamlı bulunmuştur.

\subsubsection{Kendini Gerçekleștirme Alt Boyutları ve Sınıf Arasındaki İlişki}

Öğrencilerin kișisel yönelim envanteri alt boyutları toplam puanlarının "sınıf" değişkenine göre farklılaşıp farklılaşmadığını anlamak üzere yapılan t test sonucunda elde edilen bulgular tablo 4'de verilmiștir.

\begin{tabular}{|c|c|c|c|c|c|c|}
\hline & Sinif & $\mathbf{N}$ & $\mathbf{X}$ & Ss & $\mathbf{T}$ & $\mathbf{P}$ \\
\hline \multirow[t]{2}{*}{ Kendine saygı } & 1.sinif & 68 & 11,44 & 2,48 & \multirow[b]{2}{*}{2,710} & \multirow[b]{2}{*}{$0,008 *$} \\
\hline & $2 . \sin ı f$ & 67 & 10,31 & 2,34 & & \\
\hline
\end{tabular}

Tablo 4: Kendine Saygı Alt Testi Toplam Puanlarının "Sınıf” Değişkenine Göre Farklılașıp Farklılaşmadığını Anlamak Üzere Yapılan t Test Bulguları

Buna göre öğrencilerin sınıf değişkenine göre "kendine saygı" alt boyutu aritmetik ortalamaları arasındaki fark istatistiksel olarak yüksek düzeyde anlamlı bulunmuştur.

\subsubsection{Kendini Gerçekleştirme Alt Boyutları Ve Annenin Ve Babanın Çalışma Durumu Arasındaki İlişki}

Öğrencilerin kişisel yönelim envanteri alt boyutları toplam puanlarının "Anne çalışıyor mu?" değişkenine göre farklılaşıp farklılaşmadığını anlamak üzere yapılan t test sonucunda elde edilen bulgular tablo 5'de verilmiștir. 
Dilek Erzenli Altunbayrak, Ferda Şule Kaya, “Üniversite Öğrencilerinin Kendini Gerçekleştirme Düzeyi ile Benlik Saygıları Arasındaki İlişkinin İncelenmesi”, İstanbul Gelişim Üniversitesi Sosyal Bilimler Dergisi, 6 (2), Ekim 2019, ss. 388-401.

\begin{tabular}{|c|c|c|c|c|c|c|}
\hline $\begin{array}{l}\text { Kişisel yönelim } \\
\text { envanteri alt } \\
\text { boyutları }\end{array}$ & $\begin{array}{l}\text { Anne } \\
\text { çalışıyor } \\
\text { mu? }\end{array}$ & $\mathbf{N}$ & $\mathbf{X}$ & Ss & $\mathbf{T}$ & $\mathbf{P}$ \\
\hline \multirow{2}{*}{$\begin{array}{l}\text { Başkalarıyla } \\
\text { yakınlık } \\
\text { kurabilme }\end{array}$} & Evet & 41 & 15,17 & 3,69 & \multirow{2}{*}{2,161} & \multirow{2}{*}{$0,033^{*}$} \\
\hline & Hayır & 94 & 13,44 & 4,48 & & \\
\hline \multirow{2}{*}{$\begin{array}{l}\text { İçten geldiği gibi } \\
\text { davranabilme }\end{array}$} & Evet & 41 & 11,17 & 2,07 & \multirow{2}{*}{4,833} & \multirow{2}{*}{$0,000 *$} \\
\hline & Hayır & 94 & 9,45 & 1,81 & & \\
\hline \multirow{2}{*}{$\begin{array}{l}\text { Varoluşsal } \\
\text { yaşam sürdürme }\end{array}$} & Evet & 41 & 15,41 & 3,11 & \multirow{2}{*}{2,411} & \multirow{2}{*}{$0,017^{*}$} \\
\hline & Hayır & 94 & 13,96 & 3,24 & & \\
\hline
\end{tabular}

Tablo 5: Öğrencilerin Kişisel Yönelim Envanteri Alt Boyutları Toplam Puanlarının "Anne Çalışıyor Mu?" Değişkenine Göre Farklılașıp Farklılaşmadığını Anlamak Üzere Yapılan Bağımsız $t$ Test Bulguları

"Anne çalıșıyor mu?" değișkenine göre "içten geldiği gibi davranabilme", "Varoluşsal yaşam sürdürme, "başkalarıyla yakınlık kurabilme" alt test puanlarının aritmetik ortalamaları arasındaki fark istatistiksel olarak anlamlı farklılık bulunmuștur.

Öğrencilerin kişisel yönelim envanteri alt boyutları toplam puanlarının "Baba çalıșıyor mu?" değișkenine göre farklılașıp farklılaşmadığını anlamak üzere yapılan t test sonucunda elde edilen bulgular tablo 6'de verilmiştir.

\begin{tabular}{|c|c|c|c|c|c|c|}
\hline $\begin{array}{l}\text { Kişisel yönelim } \\
\text { envanteri alt } \\
\text { boyutları }\end{array}$ & $\begin{array}{l}\text { Baba } \\
\text { çalışıyor } \\
\text { mu? }\end{array}$ & $\mathbf{N}$ & $\mathbf{X}$ & Ss & $\mathbf{t}$ & $\mathbf{p}$ \\
\hline \multirow[t]{2}{*}{ Kendine saygı } & Evet & 106 & 11,10 & 2,41 & \multirow[b]{2}{*}{2,019} & \multirow[b]{2}{*}{$0,046^{*}$} \\
\hline & Hayır & 29 & 10,06 & 2,54 & & \\
\hline \multirow{2}{*}{$\begin{array}{l}\text { Saldırganlığın } \\
\text { kabulü }\end{array}$} & Evet & 106 & 13,50 & 2,66 & \multirow[b]{2}{*}{2,637} & \multirow[b]{2}{*}{$0,009 *$} \\
\hline & Hayır & 29 & 12,03 & 2,69 & & \\
\hline
\end{tabular}

Tablo 6: Öğrencilerin Kişisel Yönelim Envanteri Alt Boyutları Toplam Puanlarının "Baba Çalışıyor Mu?"Değişkenine Göre Farklılaşıp Farklılaşmadığını Anlamak Üzere Yapılan Bağımsız t Test Bulguları

Öğrencilerin "kişisel yönelim envanteri" alt boyutlarından "Kendine saygı" ve "Saldırganlığın kabulü" alt boyutları ile "baba çalışıyor mu?" değişkeni gruplarının aritmetik ortalamaları arasında istatistiksel olarak anlamlı bir fark bulunmuștur. 
Dilek Erzenli Altunbayrak, Ferda Şule Kaya, “Üniversite Öğrencilerinin Kendini Gerçekleştirme Düzeyi ile Benlik Saygıları Arasındaki İlişkinin İncelenmesi”, İstanbul Gelişim Üniversitesi Sosyal Bilimler Dergisi, 6 (2), Ekim 2019, ss. 388-401.

\section{ilişki}

\subsubsection{Kendini gerçekleștirme alt boyutları ve aile gelir düzeyi arasındaki}

Öğrencilerin kişisel yönelim envanteri alt boyutları toplam puanlarının "aile gelir durumu" değişkenine göre fark olup olmadığını belirlemek üzere gerçekleștirilen tek yönlü varyans analizi (anova) bulguları tablo 7'da verilmiştir.

\begin{tabular}{|c|c|c|c|c|c|c|}
\hline $\begin{array}{l}\text { Kişisel yönelim } \\
\text { envanteri alt } \\
\text { boyutları }\end{array}$ & $\begin{array}{l}\text { Ailenin gelir } \\
\text { durumu }\end{array}$ & $\mathbf{N}$ & $\mathbf{X}$ & Ss & f & $\mathbf{p}$ \\
\hline \multirow{3}{*}{$\begin{array}{l}\text { Desteği içten } \\
\text { alma }\end{array}$} & $0-2000$ & 47 & 61,91 & 9,30 & \multirow{3}{*}{7,422} & \multirow{3}{*}{$0,001 *$} \\
\hline & $2100-4000$ & 66 & 68,01 & 9,27 & & \\
\hline & 4100 ve üzeri & 22 & 62,22 & 7,67 & & \\
\hline \multirow[t]{3}{*}{ Kendine saygı } & $0-2000$ & 47 & 10,42 & 2,33 & \multirow{3}{*}{3,711} & \multirow{3}{*}{$0,027^{*}$} \\
\hline & $2100-4000$ & 66 & 11,45 & 2,36 & & \\
\hline & 4100 ve üzeri & 22 & 10,13 & 2,78 & & \\
\hline \multirow{3}{*}{$\begin{array}{l}\text { Başkalarıyla } \\
\text { yakınlık } \\
\text { kurabilme }\end{array}$} & $0-2000$ & 47 & 13,02 & 4,26 & \multirow{3}{*}{4,081} & \multirow{3}{*}{$0,019 *$} \\
\hline & $2100-4000$ & 66 & 15,03 & 4,42 & & \\
\hline & 4100 ve üzeri & 22 & 12,81 & 3,44 & & \\
\hline \multirow{3}{*}{$\begin{array}{l}\text { İçten geldiği gibi } \\
\text { davranabilme }\end{array}$} & $0-2000$ & 47 & 9,89 & 1,92 & \multirow{3}{*}{5,057} & \multirow{3}{*}{$0,008^{*}$} \\
\hline & $2100-4000$ & 66 & 10,40 & 1,98 & & \\
\hline & 4100 ve üzeri & 22 & 8,86 & 2,12 & & \\
\hline \multirow{3}{*}{$\begin{array}{l}\text { Kendini } \\
\text { gerçekleştiren } \\
\text { değerleri } \\
\text { benimseme }\end{array}$} & $0-2000$ & 47 & 15,74 & 3,01 & \multirow{3}{*}{3,317} & \multirow{3}{*}{$0,039 *$} \\
\hline & $2100-4000$ & 66 & 16,95 & 2,90 & & \\
\hline & 4100 ve üzeri & 22 & 15,50 & 2,80 & & \\
\hline \multirow{3}{*}{$\begin{array}{l}\text { Varoluşsal yaşam } \\
\text { sürdürme }\end{array}$} & $0-2000$ & 47 & 13,46 & 2,93 & \multirow{3}{*}{3,609} & \multirow{3}{*}{$0,030^{*}$} \\
\hline & $2100-4000$ & 66 & 15,10 & 3,53 & & \\
\hline & 4100 ve üzeri & 22 & 14,31 & 2,60 & & \\
\hline
\end{tabular}

Tablo 7: Öğrencilerin Kişisel Yönelim Envanteri Alt Boyutları Toplam Puanlarının "Aile Gelir Durumu" Değisşkenine Göre Farklılaşıp Farklılaşmadığını Belirlemek Üzere Yapılan Tek Yönlü Varyans Analizi (ANOVA) Bulguları

Buna göre "desteği içten alma" , "içten geldiği gibi davranabilme”, kendine saygl, başkalarıyla yakınlık kurabilme , "kendini gerçekleștiren değerleri benimseme" , "varoluşsal yaşam sürdürme" alt test puanları ile "aile geliri" değişkeni aritmetik ortalamalarının arasında anlamlı farklılık bulunmuştur. 
Dilek Erzenli Altunbayrak, Ferda Şule Kaya, “Üniversite Öğrencilerinin Kendini Gerçekleştirme Düzeyi ile Benlik Saygları Arasındaki İlişkinin İncelenmesi”, İstanbul Gelişim Üniversitesi Sosyal Bilimler Dergisi, 6 (2), Ekim 2019, ss. 388-401.

\subsubsection{Kendini gerçekleştirme alt boyutları ve doğum sırası arasındaki ilişki}

Öğrencilerin kişisel yönelim envanteri alt boyutları toplam puanlarının "doğum sırası" değişkenine göre fark olup olmadığını anlamak için yapılan tek yönlü varyans analizi (Anova) sonucunda elde edilen bulgular tablo 8'da verilmiștir.

\begin{tabular}{lllllll}
\hline $\begin{array}{l}\text { Kişisel } \\
\text { yönelim alt } \\
\text { boyutları }\end{array}$ & $\begin{array}{l}\text { Doğum } \\
\text { sirası }\end{array}$ & $\mathbf{N}$ & $\mathbf{X}$ & Ss & $\mathbf{f}$ & $\mathbf{p}$ \\
\cline { 1 - 5 } $\begin{array}{l}\text { Zamanı iyi } \\
\text { kullanma }\end{array}$ & Birinci & 53 & 11,71 & 2,35 & & \\
\cline { 2 - 5 } & İkinci & 43 & 12,41 & 2,68 & $\mathbf{0 , 0 0 4 *}$ \\
\cline { 2 - 5 } & Sonuncu & 39 & 13,51 & 2,58 & \\
\hline
\end{tabular}

Tablo 8: Öğrencilerin Kişisel Yönelim Envanteri Alt Boyutları Toplam Puanlarının "Doğum Sırası" Değişkenine Göre Farklılaşıp Farklılașmadığını Belirlemek Üzere Yapılan Tek Yönlü Varyans Analizi (Anova) Bulguları

Tablo 8'de görüldüğü üzere "zamanı iyi kullanma" alt boyutu puanları ile "doğum sırası" arasında yüksek düzeyde anlamlı farklılık bulunmuștur.

\section{Tartışma ve Sonuç}

Maslow'un ihtiyaçlar teorisine göre her insanın kendine saygı ihtiyacı vardır. Kişi istikrarlı, sağlam temellere dayanan, genellikle kendisine değer biçilen benlik saygısına ihtiyaç duyar. Kendini gerçekleștirme ihtiyacının ortaya çıkabilmesi için bir önceki basamak olan kendine saygı ihtiyacının karşılanmış olması gerekir (Atkinson\&Hilgard, 2015: s. 384-385). Bu çalışmada elde edilen sonuçlara göre araştırma örneklemindeki üniversite öğrencilerinin "benlik saygısı düzeyi" ile "kendini gerçekleştirme düzeyi" arasında istatistiksel olarak anlamlı bir ilișki bulunmamıștır. Bu sonucu destekleyen çalışmalar olduğu kadar desteklemeyen çalışmalar da mevcuttur (Sungur, 2008: s. 76), (Çelik, 1993)

Bunun yanında, öğrencilerin kendini gerçekleştirme düzeyi" ile "cinsiyet" değişkeni açısından kız öğrencilerin erkek öğrencilere göre gerçekçi planlar yapma, geçmiş ve gelecekte değil de şu anda ve kimseye bağımlı olmadan yaşama, başkalarına göre değil kendi düșünce ve tecrübelerine göre karar verme eğiliminde olduklarını söylenebilir. Bu verilerin orta gelirli ailelerin çocuklarına ait olduğu da dikkate alınırsa, eğitim yolu ile sınıf atlama imkânının olması ile açlklanabilir. Orta gelir düzeyli aileler toplumun lokomotifi niteliğindedir. Orta gelirli ailelerin çocukları eğitim yolu ile sınıf atlama imkânına sahiptir ve bu imkânı ayakları üzerinde durabilen gençler yakalayabilmektedir. Bu konuda yüksek düzeyde anlamlı bir bulguya sahip olmak da durumu destekler niteliktedir. Çalışmada elde edilen bulgu Uzun'(2002)un mühendislerle ve Dünyalıŏulları (2011)'ın üniversite öğrencileri ile yaptığı çalışmalarda kadınların lehine elde edilen bulgu ile paralellik içermektedir.

$\mathrm{Bu}$ çalışmadan elde edilen bir diğer sonuç ise; birinci sınıf öğrencilerinin kendilerine saygları 2. Sınıf öğrencilerine göre daha yüksektir. Araştırmaya katılan öğrenciler meslek yüksekokulu öğrencileridir. Birinci sınıfta kendilerini meslek sahibi olarak görürken ikinci sınıfta kendilerini geliștirme ile ilgili farkındalıklarının artması ile açıklanabilir. Bu durum Torun ve Arslan(2012)'ın bulguları ile paralellik göstermektedir. 
Dilek Erzenli Altunbayrak, Ferda Şule Kaya, “Üniversite Öğrencilerinin Kendini Gerçekleştirme Düzeyi ile Benlik Saygıları Arasındaki İlişkinin İncelenmesi”, İstanbul Gelişim Üniversitesi Sosyal Bilimler Dergisi, 6 (2), Ekim 2019, ss. 388-401.

Araștırmada, öğrencilerin 5 yıl sonrasında kariyer içi hedeflerinin olmasıyla "zamanı iyi kullanma" arasında anlamlı bir ilișki bulunmuştur. Ayrıca istediği bölümde okuyan öğrencilerin de zamanı iyi kullanma alt boyutuyla istatistiksel açıdan anlamlı bir farklılık bulunmuştur. Öğrencilerin, istediği mesleği yapma, zamanı iyi kullanma ile şimdiki zamanda yaşamanın kariyer hedefine ulaşmada önemli bir durum olduğunu düşündürmektedir.

Çalıșmada ayrıca; annenin çalıșıyor olmasının gencin esnek davranma, dogmatik olmama, duygularını ve düşüncelerini rahatça ifade edebilme ve bunların sorumluluğunu alabilme, pozitif ve samimi ilişkiler kurabilme özelliklerine sahip olmasını destekler niteliktedir. Babasının çalışması ise; gençlerin öfke duygularını kabullenme ve bu duygularını uygun bir șekilde ifade edebilme, kendine saygısında olumlu katkıları olduğu da görülmüștür. Bu durum çalıșan anne ve babanın çocuğu olmanın hayatla mücadele etme ve kendine saygı açısından önemli bir durum olușturduğunu göstermektedir.

Araștırma bulguları doğum sırasına göre değerlendirildiğinde ise; son sırada doğan çocuğun șimdiki zamanda yașayabilme, geçmiș ve gelecek arasında anlamlı bağlar kurabilme geçmişten pișmanlık duymama, geleceğe ilișkin amaçlarında gerçekçi olma gibi özellikleri olduğu söylenebilir. Son çocuğun ailede daha toleranslı ve ailenin imkânlarından daha fazla faydalan çocuklar olduğunu düşündürebilir. Bu bulgu Oktan, Odacı ve Çelik (2014) tarafından üniversitesi öğrencilerinin doğum sırasıyla ilgili yapılan çalışmanın bulgularıyla paralellik içermektedir.

Sonuç olarak bu çalışmada aile geliri ve kendini gerçekleștirme alt boyutları ilişkisine bakıldığında orta gelirli ailelerin özellikle kız çocuklarının ve son çocukların kendini gerçekleștirme düzeyi anlamlı derecede yüksek olduğu sonucuna bulunmuștur. $\mathrm{Bu}$ çocuklarının otoritenin değil kendi değerlerine göre davranan, bağımlı olmayan, kendine yetebilen, ilke ve kuralları uygulamada dogmatik olmayan gençler olduğu görülmektedir.

\section{KAYNAKÇA}

ADLER, A. (2014). Çocuk Eğitimi. İstanbul: Cem Yayınevi.

ARIK, İ.A.(1992). Motivasyon Ve Heyecana Giriş, İstanbul Üniversitesi Psikoloji Bölümü 1992 Yılı Yayınlanmamıș Ders Notları

ATKINSON \& HILGARD. (2015). Psikolojiye Giriş. Ankara: Arkadaş Yayınları.

ÇELIK, S. (1993). Öğretmenlerin kişisel özellikleri ve ihtiyaçlarının karşılanma derecesi ile kendini gerçekleștirme düzeyleri arasındaki ili. Hacettepe Üniversitesi, Sosyal Bilimler Enstitüsü ,Eğitim Yönetimi, Teftişi, Planlaması ve Ekonomisi Bilim Dalı. Doktora tezi.

DAĞLI, G., \& BEYAZSAÇLI, M. (2010). Ana-Baba Tutumu ve Kendini Gerçeklestirme. Akdeniz Eğitim Araştırmaları Dergisi, 1-16.

DÜNYALIOĞULLARI, Ö. (2011). Üniversite öğrencilerinin kendilerini gerçekleştirme engelleriyle genel erteleme eğilimi ve umutsuzluk düzeyleri arasındaki ilişkinin incelenmesi. yayınlanmamış yüksek lisans tezi . Dokuz Eylül Üniversitesi Eğitim Bilimleri Enstitüsü Eğitim Bilimleri Anabilimdalı Rehberlik Ve Psikolojk Danışmanlık Programı Yüksek Lisans Tezi.

GÜRSOY, F., ARAL, N., AYHAN, A.B., \& AYDOĞAN, Y.(2004). Annesi çalışan ve çalışmayan çocukların bağımlılık eğilimlerinin incelenmesi. Hacettepe Üniversitesi Eaitim Fakültesi Dergisi, 62-71.

KAYA, F. Ş., \& UYSAL, V. (2015). Günümüzde Dindarlık Ve Toplumsal Cinsiyet Rolü Algıları Üstüne Bir Araştırma. Uluslararası Sosyal Araștırmalar Dergisi, 646-662. 
Dilek Erzenli Altunbayrak, Ferda Şule Kaya, “Üniversite Öğrencilerinin Kendini Gerçekleştirme Düzeyi ile Benlik Saygıları Arasındaki İlişkinin İncelenmesi”, İstanbul Gelişim Üniversitesi Sosyal Bilimler Dergisi, 6 (2), Ekim 2019, ss. 388-401.

KAYA, M., GÜNEŞ, G., KAYA, B., \& PEHLIVAN, E. (2004). Tıp fakültesi öğrencilerinde boyun eğici davranışlar ve șiddetle ilișkisi. Anadolu Psikiyatri Dergisi, 5-10.

KUZGUN, Y., \& BACANLI, F. (2005). PDR'de kullanılan ölçekler. Ankara: Nobel Yayın.

MASLOW, A. (1970). Motivation And Personality. by Harper \& Row, Publishers, Inc.

ODACI, H. (1994). Karadeniz Teknik Üniversitesi Fatih Eğitim Fakültesi Öğrencilerinin Yalnızlık,Benlik saygısı Ve Yakın İlișkiler Kurabilme Düzeylerinin Ve Bu Düzeyler Arasında İlişkilerin İncelenmesi. Yayınlanmamış Yüksek Lisans Tezi . Karadeniz Teknik ÜniversitesiSosyal Bilimler Enstitüsü Eğitim Bilimleri Anadalı.

OKTAN, V., ODACI, H., ÇELIKK, Ç.B., (2014). Psikolojik Doğum Sırasının Psikolojik Sağlamlılığın Yordanmasındaki Rolünün İncelenmesi. Abant İzzet Baysal Üniversitesi Eğitim Fakültesi Dergisi.

PLOTNIK, R. (2009). Psikolojiye Giriș. İstanbul: Kaknüs Yayınları.

ÖZGÜR, G., YÖRÜKOĞLU, G., \& ARABACI, L. B. (2011). Lise Öğrencilerinin Șiddet Algıları, Şiddet Eğilim Düzeyleri ve Etkileyen Faktörler. Psikiyatri Hemşireliği Dergisi , 5360 .

SUNGUR, P. (2008). Üniversite son sınıf öğretmen adaylarının benlik tasarımı ve kendini gerçekleştirme düzeyleri arasındaki ilişkinin incelenmesi. yüksek lisans tezi . Kafks Üniversitesi Sosyal Bilimler Enstitüsü Eğitim Bilimleri Anabilimdalı.

TORUN, S., ARSLAN, S., NAZIK, E., AKBAŞ, M., \& YALÇIN, S. Ö. (2012). Hemşirelik öğrencilerinin benlik saygısı ve boyun eğici davranışlarının incelenmesi. Cumhuriyet Tıp Dergisi , 399-404.

TURAN, N., \& TUFAN, B. (1989). Yüksek Öğrenim Yapan Bir grup Öğrencinin Benlik Saygılarını Dört Yıl Ara İle İzleme Çalışması. Hacettepe Sosyal Hizmetler Yüksekokulu Dergisi, 28-34.

TURAN, A. F. (2010). Üniversite öğrencilerinin ilişkilerle ilgili bilișesl çarpıtmalarını yordamada yalnızlık,benlik saygısı,yaş,cinsiyet ve romantik ilişki yaşama duruunun rolü. yayınlanmamış yüksek lisans tezi . Anadolu ünivesitesi eğitim bilimleri enstitüsü.

UZUN, H. (2002). Orman Mühendislerinin Kendini Gerçekleştirme ve İş Doyumu Düzeyleri. yayınlanmamış yüksek lisans tezi. Kocaeli Üniversitesi Sosyal Bilimler Enstitüsü.

YANBASTI, G. (1996). Kişilik Kuramları. İzmir: Ege Üniversitesi Basımevi.

\section{Summary}

Self-actualization and Self-esteem are important factors especially for university students. These elements have great impact on social relationships, future career plans and mental health. But In literature, there is limited research questioning the relationship of Selfactualisation and Self-esteem. Therefore, the aim of this study is; to investigate the relationship between self-esteem and self-realization variables of the students studying at the university. And, conducting a research in this area will contribute to the literature as well as a new source for future studies. In this study, the self-actualization level, self-esteem level and socio-demographic characteristics were used as evaluation criteria and the relations between them were examined with the colerative analysis method. "Personal Orientation Inventory" was used to evaluate the level of self-actualization level. "Coopersmith Self-Esteem Inventory" was used to evaluate the level of self-esteem and a "Personal Information From "was used to determine the socio demographic characteristics of the students As a sample group, university students who studying in vocational schools in Istanbul were selected. 
The results revealed that there was no significant relationship between self-esteem level and self-realization level of university students. But in terms of sub-dimensions this study showed that there are some different outcomes between self-actualization level and socio-demographic characteristics. Firstly, there is a significant relationship between Selfrealization and gender. And this difference is in favor of female students. According to this, we can say that female students tend to make realistic plans, to live without dependency and to rely on their own thoughts and experiences for others compared to male students. In addition, this study showed a significant relationship with family income and selfactualization level. The middle income level, rather than the high or low income level, provides a more appropriate environment for the students to realize themselves.

In our study, the students self-esteem total scores were examined according to the gender variable of the students and as a result there was a significant difference in favor of female students. In the literature, researchers who have done research on this issue have reached similar results. When these researches and research results are examined, it is thought that higher education increases the self-esteem in women. Contrary to the results of this study, there are also studies that do not find a relationship between gender and selfesteem.

As a result, the self-realization level of female students and middle-income families was found to be high. Female students were found to be significantly different from male students in terms of using time well, getting support from inside, being able to communicate with others, level of expression of emotions, behaving inwardly, adopting self-fulfilling values, and accepting aggression. 